intrusion of the ultrabasic rocks, a plagioclase magma invaded and hybridised them with the production of augite-biotite-diorite. The latter rose in turn into the zone of fusion, giving rise to hypersthene-bearing monzonites and diorites.

The granodiorite appears to have risen by stoping, since it is rich in xenoliths of the earlier hybrids and cuts across the sediments in the north-east. In places it transgresses the zone of fusion and contains xenoliths of the fused sediments. Textures and mineral and chemical composition unite in suggesting that the granodiorite is essentially a mixture of sediments and plagioclase magma with a little biotite-pyroxenite. For the most part, it clearly formed in depth and afterwards rose into its present position. The porphyritic granodiorite of Cam Lough Mountain in the west of the Complex represents the simple soaking of plagioclase magma into fused sediments.

An animated discussion followed the reading of the paper. A number of speakers, including Dr. W. Q. Kennedy, Dr. H. H. Thomas, and Mr. W. Campbell Smith, seemed suspicious about the existence of a plagioclase magma, and it was asked whether a granite magma might not be competent to produce the observed results. Miss Reynolds pointed out that since the augite-biotite-diorite is a normatively undersaturated rock almost free from quartz, it is impossible that the addition of granite to the biotitepyroxenite could have produced it. That the plagioclase came in as a magma is indicated by the observa. tion that it has dissolved all the iron ores with which it has come into contact in the biotite-pyroxenite. From the analyses it was found that the magma is composed of about 80 per cent plagioclase, with iron ores and biotite making up the balance.

Prof. A. Holmes suggested that elsewhere there is ample evidence of plagioclase magma in the existence of anorthosites. Such magma is likely to be very hot, and by syntexis with crustal rocks it would readily grade into syenitic magma, thus providing a wide range of felspathic magmas. Questions of origin are purely speculative, but this does not mean that the plagioclase magma traced by Miss Reynolds is in any way hypothetical ; its behaviour and products are demonstrable facts of observation. He welcomed the new light that the evidence from Newry will throw on the less tractable problems of volcanic fields such as that of Bufumbira. The lavas of that region include potash-rich limburgites in which he had recognised the volcanic equivalent of biotite-pyroxenite. Leucite-basanites developed by the incoming of plagioclase, and by the further addition of sialic material latites and hypersthene-trachyandesites were generated.

Prof. A. Brammall pointed out that while the wellknown Hollybush diorite of the Malverns might theoretically be referred to the granitisation of greenstones, neither field nor geochemical evidence sustains this view; all the evidence points to a genetic linkage with the biotite-pyroxenite that is present in the area. The formation of the diorite requires the addition to the biotite-pyroxenite of a magma composed of 60 per cent of andesine and rich in iron ores.

As illustrations of other igneous assemblages where there are signs of an ancestry comparable with that of the Newry Complex, Miss Reynolds cited the Loch Ailsh Complex of Scotland, the provinces of Monzoni and Predazzo, the Trondhjemite-Opdalite Series of Norway, the Cortlandt Series of the Appalachians and various examples in the Western Cordillera of North America, including the Rossland Complex described by Daly. She directed attention to the noteworthy fact, hitherto obscured by faulty nomenclature, that true gabbros are characteristically absent from many of the plutonic complexes of folded regions. Referring to the occurrence of monzonites and diorites as individual intrusions, Miss Reynolds suggested that hybridisation, which is known to have taken place at shallow depths, implies more intense activity at greater depths, resulting in the production of actual magmas capable of intrusion to higher levels.

\title{
Magnetic Recording and Reproducing in Broadcasting
}

$\Delta \mathrm{T}$ the Paris Universal Exhibition of 1900 , A Poulsen demonstrated his telegraphone as a magnetic speech recorder for use in a telephone circuit. The apparatus, in its earliest form, consisted of a steel wre or ribbon, which was passed between the poles of an electromagnet, the windings of which were supplied with the audio-frequency currents to be recorded. As the wire was drawn slowly through the field of the magnet, it received therefrom a series of transverse magnetisations corresponding to the sounds received. On the completion of the record, the process could be reversed, and by passing the steel wire between the poles of another magnet connected in series with a telephone receiver, the speech was reproduced.

Various improved forms of the apparatus were developed during the next few years, and among these was one due to Pedersen, who in 1902 succeeded in recording two telephone messages simultaneously on one steel wire, and afterwards reproducing them separately in two receivers. In general, however, the telegraphone, like many other inventions, found little application in connexion with communication technique, until it was given a new lease of life by the introduction of broadcasting.
It is now several years since the Blattnerphone, a modern form of this magnetic recorder, was introduced for recording speech and sections of programmes required for broadcasting purposes. It soon became apparent that the magnetic recording system had important advantages over the use of films or wax discs for this purpose. Among these advantages are the freedom from chemical processes, and from delicate mechanical adjustments, and also the facility with which the recording strip can be 'cleaned-up' for repeated use.

The latest form of this apparatus for commercial use in Great Britain, known as the Marconi-Stille equipment, formed the subject of an article in the Wireless World of January 5, and was also demon. strated by Marconi's Wireless Telegraph Company, Ltd. at the recent Physical Society's exhibition. The Marconi-Stille machine provides an uninterrupted record of thirty-five minutes duration; and it incorporates the necessary mechanism for driving the steel tape at a uniform speed through the electromagnetic apparatus, which produces a varying magnetic flux in the tape in the case of recording, or translates the magnetic record into currents of varying amplitude for reproduction purposes. The 
steel tape is driven by synchronous motors at a normal speed of 90 metres per minute, between two drums similar to those used in a cinematograph film projector. In its passage the tape passes in succession through three pairs of special bi-polar electromagnets, which are used in turn for 'wiping-out' any previous record, for recording and for reproducing. The heads carrying the two latter sets of magnets are provided with micrometer adjustments for controlling the separation of the pole pieces, since this adjustment affects the response characteristics. The three heads of the apparatus are connected by screened twin leads to their appropriate places on the amplifying and control panels, and means are provided for obtaining the correct level required for recording and reproduction. The recording magnet is also supplied with auxiliary direct current to operate the tape at the best part of the magnetisation characteristic for recording. A suitable audio-frequency correcting circuit is connected in the reproducing amplifier, and the proximity of the recording and reproducing heads on the apparatus enables an instantaneous comparison to be made between the input signals and the output from the equipment.

The magnetic record, once made, is permanent and may be utilised any number of times until it is wiped out by the demagnetising process for use on another programme. The whole process now finds widespread application in broadcasting services, particularly for the relaying of important or interesting programmes at different times.

\section{University and Educational Intelligence}

CAmbridge.-J. Yudkin, of Christ's College, has been appointed to the Benn W. Levy research studentship in biochemistry.

Smith's prizes have been awarded to the following candidates: K. Mi cchell, of Peterhouse, and A. J. Ward, of Emmanue! College.

Rayleigh prizes have been awarded to M. S. Bartlett, of Queen's College, and C. G. Pendse, of Downing College.

Grants from the Worts Fund have been made as follows :- $£ 50$ to $\mathrm{N}$. Bachtin towards the expense of a journey to North Thessaly, £50 to I. H. Cox towards his expenses as geologist in the Parry Islands, $£ 50$ to J. J. Keigwin towards the expenses of an expedition to the Zambezi Valley, $£ 50$ to $P$. W. Richards towards the expense of a botanical expedition to South Nigeria, $£ 40$ to W. Graham-Smith for palrontological investigations in Canada, $£ 25$ to C. W. Borgmann for metallurgieal research in Sweden, $£ 25$ to J. W. S. Pringle towards the expenses of the Cambridge Freshwater Biological Expedition to South Morocco, $£ 10$ to J.W. Welch for expenses in connexion with his study of the Qaoko tribe.

The managers of the Balfour Fund have made a grant of $£ 50$ to C. Forster-Cooper, of Trinity Hall, for researches on the fauna of the Achenarass Quarries.

J. H. Lochhead, of Christ's College, has been nominated to use the University's table at the Zoological Station at Naples from April 1 until September 30, 1934.

LEEDs.-The Vice-Chancellor, on behalf of some two hundred subscribers, presented on March 9 to Prof. Walter Garstang a radiogramophone and a cheque, as a token of appreciation from colleagues, pupils and other friends at Plymouth, Oxford, Lowestoft and Leeds. Prof. Garstang retired from the ehair of zoology last year.

LoNDon.-The following degrees have recently been awarded: D.Sc.(Econ.) to A. E. Feavearyear (private study) for two published works entitled "The Pound Sterling. A History of English Money", and "Spending the National Income"; and D.Sc. in physics to W. E. Williams (recognised teacher at King's College) for ten works on interferometry.

SHEFFIELD. -The following appointments have been made: Dr. E. J. Wayne, to the chair of pharmacology; Dr. James Clark, to the lectureship in infectious diseases; Mr. H. Laithwaite, as junior research assistant in the Department of Glass Technology.

THE Board of Education is prepared to consider applications for full-time studentships from teachers with at least five years' teaching experience who desire financial assistance to follow courses of advanced study at universitios or other institutions at home or abroad. Particulars of the awards and application forms are obtainable from the Board of Education, Whitehall, S.W.1.

\section{Science News a Century Ago}

\section{Capt. John Ross Honoured}

In 1829, thanks to the generosity of Sheriff Felix Booth, Capt. John Ross had been able to fit out the steam vessel Victory for aretic exploration. Ross sailed in May 1829 and returned home in October 1833 in the Isabella, the Victory having had to be abandoned in the ice. On March 27, 1834, at a Court of Common Council, Ross was presented with the freedom of the City of London. In making the presentation, Sir James Shaw, the Chamberlain of the City, said : "Captain Ross-The City of London have ever been forward in bestowing the honour of their freedom on eminent men who have distinguished themselves in the service of the public. In your person science has been largely and specially indebted for the zeal, public spirit and disinterestedness shown by you in fitting out and taking charge of an expedition, with the patriotic view to the solution of the problem whether a north-west passage existed to the Pacific. For the courage and perseverance which have marked the whole of your proceedings in this hazardous enterprise, and for the admirable skill and address manifested by you, with the blessing of Heaven, in preserving life and health and harmony amongst your brave companions, amidst the privations and hardships of four years' navigation in the Arctic regions;-for these services the Corporation of London have recorded their grateful thanks by presenting you with the freedom of their ancient city in a box of British oak."

\section{J. D. Forbes at Edinburgh}

When J. D. Forbes in 1833 was appointed to succeed Sir John Leslie as professor of natural philosophy in the University of Edinburgh, he was not twenty four years of age and had held no appoint. ment before. When preparing his lectures, he wrote 